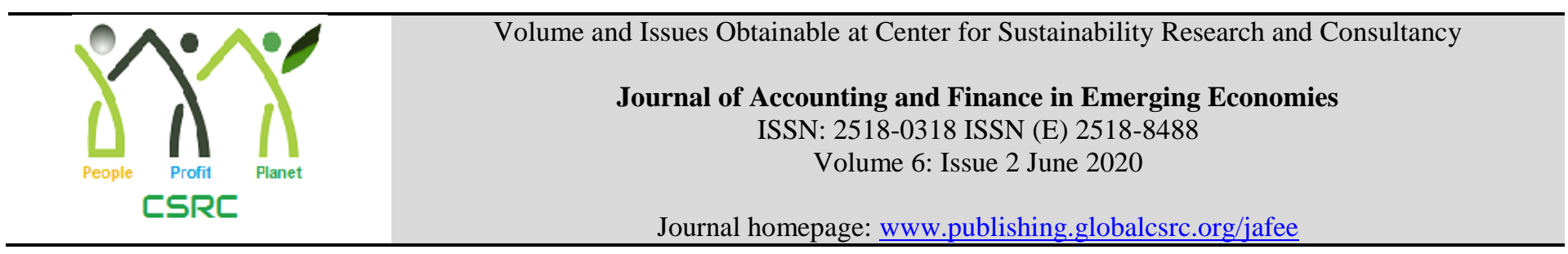

\title{
Financial Autonomy for Unemployed and Disadvantaged Adolescents with Disabilities through Punjab Vocational Training Institutions
}

\author{
${ }^{1}$ Ghulam Fatima, ${ }^{2}$ Rukhsana Bashir, ${ }^{3}$ Samina Ashraf, ${ }^{4}$ Dur e Nayab \\ ${ }^{1}$ Associate Professor, Institute of Education and Research, University of the Punjab, Lahore Pakistan, \\ fatima.ier@pu.edu.pk \\ ${ }^{2}$ Assistant Professor, Department of Special Education, University of the Punjab, Lahore Pakistan, \\ rukhsana.dse@gmail.com \\ ${ }^{3}$ Assistant Professor, Department of Special Education, University of the Punjab, Lahore Pakistan, \\ miss_saminadse@yahoo.com \\ ${ }^{4}$ Phd Scholar,_Institute of Education and Research, University of the Punjab, Lahore Pakistan, \\ durenayab18@yahoo.com
}

\section{ARTICLE DETAILS}

\section{History}

Revised format: May 2020

Available Online: June 2020

\section{Keywords}

Awareness, underprivileged, students with disabilities, demand driven skill training

JEL Classification

$F 1, F 3$

\begin{abstract}
The central focus of this quantitative exploration was to know the awareness level of poor and disadvantaged students with disabilities (hearing impaired, visually impaired, physically handicapped and mild mentally challenged) about demand driven skill training provided by Punjab Vocational Training Institutions. A sample of 105 students with disabilities (male and female) enrolled in elementary and secondary level special education schools and centres located in Lahore division were selected through simple random sampling technique. A self developed and validated questionnaire (Cronbach Alpha 0.92) on five point Likert scale was used to elicit their responses. Descriptive statistics were used for data analysis. ANOVA was employed to find difference in awareness level among the students of four disabilities, $t$ test was used to find difference on the basis of gender, type of schools (public \& private), and locale (urban \& rural). No significant mean difference was found on the basis of gender. There was a significant difference on the basis of type of schools and disabilities. Recommendations were made to Government of the Punjab, Punjab Special Education Department, and private sector to increase employability through the enrolment of students with disabilities in Punjab Vocational Training Institutions.
\end{abstract}

\section{OPEN ACCESS}

(C) 2020 The authors, under a Creative Commons Attribution-

NonCommercial 4.0

Corresponding author's email address: fatima.ier@pu.edu.pk

Recommended citation: Fatima, G., Bashir, R., Ashraf, S. \& Nayab, D. (2020). Financial Autonomy for Unemployed and Disadvantaged Adolescents with Disabilities through Punjab Vocational Training Institutions.

Journal of Accounting and Finance in Emerging Economies, 6(2), 635-641 


\section{Introduction}

The great challenge faced by almost every young person is his transition from vocational training to employment because it is a great determinant of the future life of a person. Vocational training is the implementation of learned skills practically and it gives a connection between education and the world of work. Vocational training is included in the curricula at the high school level or in the post-secondary vocational institutions. The provision of timely resources and opportunities are important in an individual's life to teach him suitable vocational skills (Ziguras, 2005). The same is true for young people with disabilities. They have to face great challenges and remarkable fears which get intensity in the presence of a disability. As a result, the risk of social exclusion increases for young people who are in phase of transition and have a disability (Wakeford \& Waugh, 2014).

Punjab Vocational Training Council (PVTC) was founded in Oct. 1998. The Government of the Punjab (GOP) laid its foundations with the concept of a collaboration between private and public sector. This institution is using charity money for decrease in poverty through skill development and provision of training to disadvantaged young community in their neighbourhood through the cooperation of private organizations to increase job opportunities. It also aims to help the graduates in their permanent job placement and rehabilitation through making arrangements for monetary assistance to enhance self-employability. The proposal is to get financed from Micro Finance Institutions and Non- Government Organizations. Punjab Vocational Training Council is an exemplary model in the Muslim World which is using Zakat as a source of providing expertise and financial autonomy to the underprivileged youth. It has opened new horizons to channelize Zakat (giving alms to the needy segments of society in Islam) to support an operative programme of vocational training for the rehabilitation of the deserving youth on sound footing. The research studies conducted by EEA, USAID and IYF have also appreciated the efforts of PVTC for providing training and jobs to the young boys and girls who were lacking in economic resources for receiving vocational and technical skills. This council has planned to provide training to half million trainees (www.pvtc.gop.pk).

\subsection{Background of the Study}

Transition from vocational training to employment is challenging as well as critical for almost every young person because it helps to determine a person's future life. The hand-on implementation of acquired skills is focused in imparting vocational training and it connects the education sector with the world of work. Vocational training is generally imparted at the level of high school or in a vocational school at post- secondary level. Certainly, research has shown that adequate vocational skills are important in an individual's life and it requires timely resources and support services (Ziguras, 2005). It is specifically accurate for youth with special needs as well. These young persons face significant insecurities and great development related issues which become more hazardous when they are having some sort of disability (Yu 2009; Blacher 2001; Dewson et al. 2004; Lichtenstein 1998; Winn and Hay 2009). Therefore, systematic and strategic planning is required for vocational training and employment of persons with special needs.

The vocational rehabilitation system and its role in facilitating the employment of individuals with disabilities, has been the subject of several accounts. The role of school is very important in planning and implementation of vocational rehabilitation plan for students with special needs. Individual with Disability Act (2004) also endorsed that schools are required the type of education system that facilitates student transition from school to adulthood and focuses on their employment goals as well.

\subsection{Rationale of the Study}

World Health Organization (WHO) has enumerated that around one billion individuals or 15\% of the population globally are having some type of disabilities. In the case of Pakistan, the incidence of disability has been guessed as 2.49\% (CRPD, Article 31;Population Census, 1998). On the basis of statistics about the population of children and adults with disabilities in Pakistan and the estimation of WHO (10\% of the population), and information provided by the local agencies and Population Census, 1998, the National Policy for Persons with Disabilities (2002) was framed. The following table shows the distribution of $2.49 \%$ statistics on the basis of age and optimal need level: 


\begin{tabular}{|l|l|}
\hline Children under 5 and their families who need any sort of assistance & $10.34 \%$ \\
\hline Children between 5-14 years who need any type of special instruction & $23.09 \%$ \\
\hline $\begin{array}{l}\text { Young individuals till 29 who will require more education, training and } \\
\text { opportunities for employment }\end{array}$ & $23.98 \%$ \\
\hline Adults with disabilities who need other help and support & $25.15 \%$ \\
\hline $\begin{array}{l}\text { The senior citizens with disabilities who require more disability } \\
\text { specific facilities }\end{array}$ & $16.56 \%$ \\
\hline
\end{tabular}

The National Census Report (1998)

According to the 1998 census, the following table presents the division of persons with disabilities within the range of specific disabilities:

\begin{tabular}{|l|l|l|}
\hline i. & Persons with physical disabilities & $19 \%$ \\
\hline ii. & Persons with mental handicaps & $14 \%$ \\
\hline iii. & Persons with multiple disabilities & $8.21 \%$ \\
\hline iv. & Persons with visual Impairment & $8.6 \%$ \\
\hline v. & Persons with hearing Impairment & $7.40 \%$ \\
\hline vi. & $\begin{array}{l}\text { Other disabilities which are not categorized } \\
\text { but are considered as disabilities }\end{array}$ & $43.33 \%$ \\
\hline
\end{tabular}

The National Census Report (1998)

As indicated by The National Census Report of 1998, there are $23.98 \%$ persons with disabilities upto the age of 29 years who need further education, training and employment opportunities. In the light of this information, it is imperative to conduct studies for creating awareness among persons/adolescents with disabilities, their teachers and parents to avail opportunities of training and employment offered by the government.

\subsection{Objectives of the Study}

The following objectives were framed for the study:

1. To explore awareness level of unemployed and poor adolescents with disabilities about available resources of demand driven skill training.

2. To create awareness among unemployed and needy adolescents with disabilities about existing opportunities of vocational training.

3. To give recommendation to Punjab Special Education Department and Punjab Vocational Training Council for providing opportunities to unemployed and poor adolescents with disabilities for their vocational training.

\subsection{Questions of the Study}

The following questions were formulated to achieve the objectives of the study:

1. What is the awareness level of unemployed and poor adolescents with disabilities about available resources of demand driven skill training.

2. How can awareness be created among unemployed and needy adolescents with disabilities about existing opportunities of vocational training.

3. How much willingness has been created among unemployed and needy adolescents with disabilities regarding skill training program of Punjab Vocational Training Institutions?

\section{Method}

The study was a descriptive survey research in nature. Target population of the study included all the unemployed and needy adolescents having disabilities registered in Government Special Schools and Centres located in Lahore division. The study was conducted in Lahore division in Punjab. All Government Special Schools and Centres located in all tehsiles of the Lahore division were taken for the selection of sample. All 105 needy adolescents with disabilities (male and female) enrolled in elementary and secondary classes were taken for the collection of data. A 
questionnaire which was self developed and validated and prepared on five point Likert type scale was used to identify awareness of unemployed and needy adolescents with disabilities about available resources of demand driven skill training for them.

\subsection{Data Collection Procedure}

The data were collected through the following procedure:

1. Time schedule was made for collecting data through questionnaires.

2. The dates and timings was fixed after consulting with heads of institutions and getting their approval. The availability and ease of the research participants was kept into consideration while deciding date and time.

3. The respondents were assured of the anonymity and confidentiality of the information provided by them.

4. To assess awareness of enrolled unemployed and needy adolescents with disabilities, data were gathered by research assistants (hired) after imparting training in collecting data and filling up of questionnaires.

\subsection{Validity and Reliability of Instruments}

The content validity of the questionnaires was ensured by professional and technical experts in the field of vocational and special education. After ensuring content validity, the instrument was pilot tested through obtaining data from 10 participants. The value of Cronbach alpha (.92) was identified to estimate the reliability of the instruments.

\subsection{Data Analysis Techniques}

Descriptive data analysis programme was used to analyze the data. Independent Sample $t$-test was used to find difference in awareness of male and female adolescents with disabilities. Similarly independent sample $t$-test was used to find mean difference in the awareness of adolescents with disabilities. Analysis of variance (ANOVA) was applied to identify mean difference in the awareness level of unemployed and needy adolescents with disabilities after field activities. Descriptive statistics were used to identify effectiveness of field activities.

\section{Major Findings and Results}

The major findings and results are presented as under:

Table 01

The results of ANOVA applied on all four parameters on the basis of class of subjects

\begin{tabular}{|c|c|c|c|c|c|c|}
\hline & & & & Mean & & \\
\hline & & $\mathrm{SS}$ & $d f$ & Square & $F$ & Sig. \\
\hline $\begin{array}{l}\text { Skills after passing } \\
\text { primary level }\end{array}$ & $\begin{array}{l}\text { Between } \\
\text { Groups }\end{array}$ & 1749.902 & 4 & 437.476 & 3.643 & .024 \\
\hline & Within Groups & 2161.750 & 18 & 120.097 & & \\
\hline & Total & 3911.652 & 22 & & & \\
\hline $\begin{array}{l}\text { Skills after passing } \\
\text { middle level }\end{array}$ & $\begin{array}{l}\text { Between } \\
\text { Groups }\end{array}$ & 4024.859 & 4 & 1006.215 & 4.250 & .014 \\
\hline & Within Groups & 4261.750 & 18 & 236.764 & & \\
\hline & Total & 8286.609 & 22 & & & \\
\hline $\begin{array}{l}\text { Skills after passing } \\
\text { matric level }\end{array}$ & $\begin{array}{l}\text { Between } \\
\text { Groups }\end{array}$ & 455.067 & 4 & 113.767 & 1.195 & .347 \\
\hline & Within Groups & 1714.150 & 18 & 95.231 & & \\
\hline & Total & 2169.217 & 22 & & & \\
\hline $\begin{array}{l}\text { Skills after passing } \\
\text { intermediate level }\end{array}$ & $\begin{array}{l}\text { Between } \\
\text { Groups }\end{array}$ & 115.404 & 4 & 28.851 & .518 & .723 \\
\hline
\end{tabular}




\begin{tabular}{llll}
\hline Within Groups & 1001.900 & 18 & 55.661 \\
Total & 1117.304 & 22 & \\
\hline
\end{tabular}

Table 1 shows results of one way ANOVA to identify mean difference in responses of unemployed and poor adolescents with disabilities about the learning of skills after a certain level of education. Results of the table are showing that there is substantial mean difference in responses of unemployed and poor adolescents with disabilities who have passed primary level $\mathrm{F}(4)=3.64, \mathrm{p}<.05$. It is also evident that there is statistically noteworthy mean difference in responses of unemployed and poor adolescents with disabilities who have passed middle level $\mathrm{F}(4)=$ $4.25, \mathrm{p}<.05$. Table values are also showing that there is no important mean difference in responses of unemployed and poor adolescents with disabilities who have passed Matric level $F(4)=1.19, p=.35$. Similarly, there is no substantial mean difference in responses of unemployed and poor adolescents with disabilities who have passed Intermediate level $\mathrm{F}(4)=.52, \mathrm{p}=.72$.

Table 02

ANOVA on the basis of institutions of participants

\begin{tabular}{|c|c|c|c|c|c|c|}
\hline & & SS & $d f$ & Mean Square & $F$ & Sig. \\
\hline \multirow[t]{3}{*}{ Skills after passing primary level } & $\begin{array}{l}\text { Between Groups } \\
\text { (BG) }\end{array}$ & 96.068 & 2 & 48.034 & .252 & .780 \\
\hline & $\begin{array}{l}\text { Within Groups } \\
\text { (WG) }\end{array}$ & 3815.584 & 20 & 190.779 & & \\
\hline & Total $(\mathrm{T})$ & 3911.652 & 22 & & & \\
\hline \multirow[t]{3}{*}{ Skills after passing middle level } & BG & 141.772 & 2 & 70.886 & .174 & .842 \\
\hline & WG & 8144.836 & 20 & 407.242 & & \\
\hline & $\mathrm{T}$ & 8286.609 & 22 & & & \\
\hline \multirow[t]{3}{*}{ Skills after passing matric level } & BG & 508.594 & 2 & 254.297 & 3.063 & .069 \\
\hline & WG & 1660.623 & 20 & 83.031 & & \\
\hline & $\mathrm{T}$ & 2169.217 & 22 & & & \\
\hline \multirow[t]{3}{*}{ Skills after passing intermediate level } & BG & 105.611 & 2 & 52.805 & 1.044 & .370 \\
\hline & WG & 1011.694 & 20 & 50.585 & & \\
\hline & $\mathrm{T}$ & 1117.304 & 22 & & & \\
\hline
\end{tabular}

Table 2 is showing results of one way ANOVA to identify mean difference in responses of unemployed and poor adolescents with disabilities about the learning of skills who have completed their education from different institutions. Results of the table are showing that there is no statistically substantial mean difference in responses of unemployed and poor adolescents with disabilities who have passed primary level from different institutions $\mathrm{F}(2)=$ 
$2.52, \mathrm{p}=.78$. It is also obvious that there is no statistically significant mean difference in responses of unemployed and poor adolescents with disabilities who have passed middle level from different institutions $\mathrm{F}(2)=1.74$, $\mathrm{p}<.84$. Table values are also showing that there is no important mean difference in responses of unemployed and poor adolescents with disabilities who have passed Matric level from different institutions $F(2)=3.06$, p = .07 . Similarly, there is no statistically noteworthy mean difference in responses of unemployed and poor adolescents with disabilities who have passed Intermediate level from different institutions $\mathrm{F}(4)=1.04, \mathrm{p}=.37$.

Table 03

The results of ANOVA applied on the basis of class/grade of respondents

\begin{tabular}{|c|c|c|c|c|c|}
\hline & SS & $d f$ & Mean Square & $f$ & Sig. \\
\hline Between Groups & 968.128 & 2 & 484.064 & .291 & \\
\hline Within Groups & 33239.351 & 20 & 1661.968 & & \\
\hline Total & 34207.478 & 22 & & & \\
\hline
\end{tabular}

Table 04

Independent sample t-test on the basis of residential area of the respondents

\begin{tabular}{|c|c|c|c|c|c|c|}
\hline & & $F$ & Sig. & $t$ & $d f$ & Sig. (2-tailed) \\
\hline $\begin{array}{l}\text { Total } \\
\text { Scores }\end{array}$ & $\begin{array}{l}\text { Equal variances } \\
\text { assumed }\end{array}$ & .438 & .516 & .489 & 21 & .630 \\
\hline
\end{tabular}

The results of independent sample $t$-test to show mean difference in responses of unemployed and poor adolescents with disabilities about the awareness of skills on the basis of their areas of residence. Results of the table are showing that there is no substantial mean difference in responses of unemployed and poor adolescents with disabilities living in urban and rural areas $t(21)=.489, \mathrm{p}=.63$.

\section{Discussion on Major Findings}

Major findings revealed that there was statistically significant mean difference in responses of unemployed and poor adolescents with disabilities who had passed primary and middle level. It means that their level of awareness regarding learning of skills provided by Punjab Vocational Training Institutions was different. It shows that some of them were having more awareness about these skills than others. On the other hand, the awareness level of adolescents with disabilities at Matric and Intermediate level regarding provision of skills was the same. It means that at this level of age, the adolescents with disabilities are more aware of the available skills than others at lower level of education. Moreover, no statistically significant difference was found among the awareness level of adolescents with disabilities enrolled at primary, middle, matric and intermediate level in different schools and centres. It reflects that all schools and centres are providing awareness to them on equal level. 
Similarly, there was no statistically significant difference in the awareness level of adolescents with disabilities studying in different grades regarding the provision of skills by Punjab Vocational Training Institutions. No statistically significant difference was found in the awareness level of adolescents with disabilities on the basis of their areas of residence. It means that the adolescents with disabilities residing either in urban or rural area were having same awareness level about the available skills.

\section{Recommendations}

The following recommendations are made on the basis of major findings:

1. The skills being taught by the Punjab Vocational Training Institutions should be introduced in the Government Special Education schools and centres.

2. The unemployed and disadvantaged adolescents with disabilities should be provided with opportunities to learn about the skills being taught by the Punjab Vocational Training Institutions.

3. Directorate General of Special Education should develop a liaison with Punjab Vocational Training Council for the provision of skills related training to unemployed and needy adolescents having disabilities enrolled in Government Special Education Institutions in Punjab.

\section{References}

Directorate of Special Education, Government of the Punjab. (2015). The annual budget estimation for the year 2013 2014. Lahore: Ministry of Special Education.

Directorate of Special Education, Government of the Punjab. (2015). District wise budget allocation for the year 2013-2014. Lahore: Ministry of Special Education.

Directorate of Special Education, Government of the Punjab. (2015). List of special education institutions in Punjab 2013.Lahore: Ministry of Special Education.

Directorate of Special Education, Government of the Punjab. (2013). Devolved Special Education Institutions and Children's Enrolment Rate up to November 2013. Lahore: Ministry of Special Education.

Directorate of Special Education, Government of the Punjab. (2015). Disability and Gender Wise Enrolment of Children in Special Education Institutions of the Provincial Government of the Punjab. Lahore: Ministry of Special Education

Government of Pakistan (2002).National policy for persons with disabilities 2002. Islamabad: Ministry of Women Development, Social Welfare and Special Education. Retrieved from http://siteresources.worldbank.org/PAKISTANEXTN/Resources/pdf-Files-in-Events/Pak-Disabled-Policy.pdf. Government of Pakistan (1998). Pakistan Population Census 1998. Islamabad: Pakistan Census Organization. Retrieved from www.pbs.gov.pk/content/population-census

Pakistan Unemployment rate. Retrieved from www.tradingeconomics.com/pakistan/unemployment-rate on dated May, 2017.

Punjab Vocational Training Council. Retrieved from http://pvtc.gop.pk/ on dated May, 2017.

United Nations Convention for Person with Disabilities (2006). Retrieved from https://www.un.org/development/desa/disabilities/convention-on-the-rights-of-persons-withdisabilities/convention-on-the-rights-of-persons-with-disabilities-2.html

Wakeford, M., \& Waugh, F. (2014). Transitions to Employment of Australian Young People with Disability and the Ticket to Work Initiative. National Ticket to Work Network, Australia. Retrieved from http://www.downsyndrome.org.au/documents/research/Executive-Summary-Transitions-to-Employment-ofAustralian-Young-People-with-Disability.pdf

World Health Organization. (2015). Retrieved from http://www.who.int/mediacentre/factsheets/fs352/en/

Ziguras, S. (2005). Transitions and risks of exclusion in the Australian labour market. paper presented at 'In Transitions and Risk: New Directions in Social Policy conference', Centre for Public Policy, University of Melbourne. 